noglobulin secretion in response to pokeweed mitogen in sarcoidosis. Clin Exp Immunol 49:96

14. Lotzova E, Savary CA, Keating MJ 1983 Studies on the mechanism of defective natural killing in leukemia-diseased patients. Exp Hematol 10:83

15. Lotzova E, Savary CA, Gutterman JU, Hersh EM 1982 Modulation of natural killer cells-mediated cytotoxicity by partially purified and cloned interferon$\alpha$. Cancer Res 42:2480

16. Lotzova E, McCredie KB, Muesse L, Dicke KA, Freireich EJ 1979 Natural killer cells in man: their possible involvement in leukemia and bone marrow transplantation. In: Experimental Hematology Today. Springer-Verlag, New York, pp 207-213

17. Lozzio CB, Lozzio BB 1972 Human chronic myelogenous leukemia cell line with positive Philadelphia chromosome. Blood 45:321

18. Mackler BF, O'Neill PA 1979 T-lymphocyte induction of non-T-cell-mediated nonspecific cytotoxicity. II. A clinical study of a severe combined immunodeficiency patient maintained in gnotobiotic environment. Clin Immunol Immunopathol 12:358

19. Mukhopadhyay N, Richie E, Montgomery JR, Wilson R, Fernbach DJ, South MA 1976 Peripheral blood T and B cell characteristics in a patient with severe combined immunodeficiency (SCID) maintained in a gnotobiotic environment. Exp Hematol 4:1

20. Mukhopadhyay N, Richie E, Mackler BF, Montgomery JR, Wilson R, Fernbach DJ, South MA 1978 A longitudinal study of T and B lymphocytes from a three-year-old patient with severe combined immunodeficiency (SCID) in gnotobiotic protection. Exp Hematol 6:129

21. Pahwa SG, Pahwa RN, Good RA 1980 Heterogeneity of B lymphocyte differentiation in severe combined immunodeficiency disease. J Clin Immunol 66:534

22. Reinherz EL, Cooper MD, Schlossman SF, Rosen FS 1981 Abnormalities of $\mathrm{T}$ cell maturation and regulation in human beings with immunodeficiency diseases. J Clin Invest 68:699

23. Rosenberg SA, Lipsky PE 1979 Monocyte dependence of pokeweed mitogeninduced differentiation of immunoglobulin-secreting cells from human peripheral blood mononuclear cells. J Immunol 122:926
24. Seeger RC, Robins RA, Stevens RH, Klein RB, Waldman OJ, Zeltzer PM, Kessler SW 1976 Severe combined immunodeficiency with B lymphocytes: in vitro correlation of defective immunoglobulin production by addition of normal T lymphocytes.Clin Exp Immunol 26:1

25. Siegal FP, Siegal M, Good RA 1976 Suppression of B cell differentiation by leukocytes from hypogammaglobulinemic patients. J Clin Immunol 58:109

26. South MA, Montgomery JR, Richie E, Mukhopadhyay N, Criswell BS, Mackle BF, DeFasio SR, Bealmear P, Heim LR, Trentin JJ, Dressman GR, O'Neill P 1977 A special report: four-year study of a boy with combined immune deficiency maintained in strict reverse isolation from birth. IV. Immunologic studies. Pediatr Res 11:71

27. Waldmann TA, Broder S, Blaese RM, Durm M, Blackman M, Strober W 1974 Role of suppressor $\mathrm{T}$ cells in pathogenesis of common variable hypogammaglobulinemia. Lancet 2:609

28. Waldmann TA, Strober W, Baese RM $1980 \mathrm{~T}$ and B cell immunodeficiency diseases. In: Parker CW (ed) Clinical Immunology, Chap 11. WB Saunders Company, Philadelphia

29. Williamson AP, Montgomery JR, South MA, Wilson R 1977 A special report: four year study of a boy with combined immunodeficiency maintained in strict reverse isolation from birth. Pediatr Res 11:63

30. Wybran J, Carr MC, Fudenberg HH 1972 The human rosette-forming cells as a marker of a population of thymus-derived cells. J Clin Invest 51:2537

31. We thank Dr. Ralph D. Feigin for a critical review of the manuscript, nurses Brynn Holcombe, Donna Aldrich, and Lynn Franklin for obtaining blood specimens and maintaining the patient's isolator system, and Ms. Peggy Jackson for preparation of the manuscript.

32. This work was supported by General Clinical Research Center Grant RR00188, the John P. McGovern Foundation, and a special fund from Texas Children's Hospital.

33. Correspondence should be addressed to Dr. William T. Shearer, Allergy and Immunology Section, Department of Pediatrics, Baylor College of Medicine, 12000 Moursund Avenue, Houston, TX 77030.

34. Received for publication January 9, 1984.

\title{
Prevention of Neonatal Hyperbilirubinemia in Rhesus Monkeys by Tin-protoporphyrin
}

\author{
CHARLES E. CORNELIUS ${ }^{(21)}$ AND PAMELA A. RODGERS \\ California Primate Research Center, University of California, Davis, California USA
}

\begin{abstract}
Summary
Rhesus monkey infants were injected subcutaneously at birth with 12 to $100 \mu \mathrm{mol}$ of tin-protoporphyrin IX, a competitive inhibitor of microsomal heme oxygenase. The elevated unconjugated serum bilirubin levels of the neonates receiving this metalloporphyrin rapidly declined to near adult levels by 24-30 h. Control neonates which received an injection of saline exhibited normal physiologic hyperbilirubinemias of from 3-6 mg/dl by 12-24 $\mathrm{h}$ as expected. These studies establish the effectiveness of tin-protoporphyrin IX in depressing bilirubin production and preventing physiologic hyperbilirubinemia in simian neonates. Two of six animals receiving the metalloporphyrin exhibited signs of toxicity.
\end{abstract}

Physiologic jaundice in the newborn human infant has been the subject of intensive investigation for many years $(10,13)$. Studies have been generally limited to the measurement of single physiologic mechanisms in neonates; this has made interpretations difficult as to the effects of bilirubin overload (10), deficient hepatic UDP-glucuronyltransferase activity $(4,7)$, and defective hepatocellular uptake of unconjugated bilirubin $(8,14)$. Due to the absence of physiologic jaundice in the guinea pig (8) and the presence of only a transient hyperbilirubinemia $(<1 \mathrm{mg} / \mathrm{dl})$ in neonatal rats (6), the newborn rhesus monkey which exhibits a marked physiologic hyperbilirubinemia appears to be the animal model of choice for future studies (10).

Rhesus monkey neonates exhibit a two-phase pattern of physiologic unconjugated hyperbilirubinemia similar to that observed in humans, although of shorter duration (10). It has also been observed that newborn rhesus monkeys excrete bilirubin conjugates into bile at rates 5 -fold greater than those of mature animals $(9,10)$. The increased load of bilirubin presented to the human neonate's liver could possibly occur from increased bilirubin synthesis (16) and/or augmented enteric reabsorption of bilirubin (18). Interruption of the enterohepatic circulation of bilirubin through bile diversion from the intestine significantly reduces the bilirubin load presented to the liver (18). It has been postulated that the bilirubin monoglucuronide excreted by the neonate into the intestine $(2,3)$ may be more easily deconjugated and reabsorbed into the enterohepatic circulation than is bilirubin 
diglucuronide which is the primary pigment excreted by adult primates (11).

Since bilirubin synthesis in human neonates is at least two to three times greater on the first day of life than in adults (16), any biologic process which slows synthesis in neonates should in turn reduce the bilirubin load and ameliorate physiologic neonatal hyperbilirubinemia. Maines (15) and Drummond and Kappas (6) recently studied the effects of various metalloporphyrins in rats on the activity of hepatic, splenic, and renal microsomal heme oxygenase, a rate-limiting enzyme in bilirubin production. Tin-protoporphyrin IX was particularly effective as a competitive inhibitor of heme oxygenase. The substantial elevations of tissue heme oxygenase activities that are present immediately after birth in neonatal rats were prevented by a single administration of tin-protoporphyrin $(5,6)$. Serum bilirubin levels declined within $24 \mathrm{~h}$ and remained near adult levels thereafter.

The present study was designed to simply test the effects of tin-protoporphyrin IX on simian neonates, which like human infants, exhibit a similar physiologic hyperbilirubinemia.

\section{MATERIALS AND METHODS}

Twelve rhesus monkey (Macaca mulatta) neonates were obtained for study at the California Primate Research Center. All pregnancies were uncomplicated and delivered by either cesarian section at 158-162 days of gestation as determined by timemated breedings or by normal spontaneous birth. All infants were successfully nursed by their mothers except for animals $C$ 2 and T 25 which received Enfamil (Mead Johnson) by bottle. Chronologic age and body weight at the time of first bleeding, mode of delivery, and subcutaneous injected doses of tin-protoporphyrin IX or saline are presented in Table 1. Untreated neonates served as controls by receiving a total of $2 \mathrm{ml}$ of sterile physiologic saline injected subcutaneously at birth in 2 divided doses. Five other neonates received between 12 and $100 \mu \mathrm{mol}$ of tin-protoporphyrin IX (Porphyrin Products, Logan, UT) subcutaneously, also in 2 divided doses. The tin-protoporphyrin IX was first dissolved in $0.2 \mathrm{ml}$ of $6 \mathrm{~N} \mathrm{NaOH}$ and $0.5 \mathrm{ml}$ of $\mathrm{NaH}_{2} \mathrm{PO}_{4}$ buffer ( $\mathrm{pH}$ 7.4). After thorough mixing, $1 \mathrm{ml}$ of sterile saline was added and the solution was carefully back-titrated dropwise with $6 \mathrm{~N} \mathrm{HCl}$ to near neutrality to prevent precipitation of the tinprotoporphyrin. Final volume injected was $2 \mathrm{ml}$. Serum samples were obtained at birth or shortly thereafter and in most cases up to $96 \mathrm{~h}$. Approximately $1 \mathrm{ml}$ of venous blood was drawn at each bleeding; the total amount of blood drawn in the neonates during the $96-\mathrm{h}$ period never exceeded $15 \%$ of blood volume.

Serum bilirubin concentrations were determined by the

Table 1. Chronological age and body weight at time of first bleeding and the injection; mode of delivery; sex; and treatment with tin-protoporphyrin IX (Tin-P)

\begin{tabular}{|c|c|c|c|c|c|}
\hline Animal* & Age (hr) & $\begin{array}{c}\text { Body } \\
\text { weight }(g)\end{array}$ & Delivery $\dagger$ & Sex & Treatment \\
\hline $\mathrm{C}_{1}$ & 1 & 439 & $\mathrm{CS}$ & $\mathrm{F}$ & $2 \mathrm{ml}$ saline \\
\hline C 2 & 1 & 635 & CS & $\mathrm{M}$ & $2 \mathrm{ml}$ saline \\
\hline C 3 & 1 & 480 & SV & $\mathbf{M}$ & $2 \mathrm{ml}$ saline \\
\hline C 4 & 1 & 565 & SV & F & None \\
\hline C 5 & 1 & 460 & SV & $\mathrm{F}$ & None \\
\hline C 6 & $6 \ddagger$ & 460 & SV & $\mathbf{M}$ & None \\
\hline T 12 & 1 & & CS & $\mathbf{M}$ & $12 \mu \mathrm{mol}$ Tin-P \\
\hline Т 25a & 1 & 590 & $\mathrm{CS}$ & M & $25 \mu$ mol Tin-P \\
\hline T 25b & 1 & 545 & $\mathrm{CS}$ & $\mathrm{M}$ & $25 \mu \mathrm{mol} \mathrm{Tin}-\mathrm{P}$ \\
\hline T 50 & 1 & 650 & $\mathrm{CS}$ & $\mathbf{M}$ & $50 \mu \mathrm{mol}$ Tin-P \\
\hline $\mathrm{T} 100 \mathrm{a}$ & 1 & 600 & SV & $\mathbf{M}$ & $100 \mu$ mol Tin-P \\
\hline $\mathrm{T} 100 \mathrm{~b}$ & $6 \ddagger$ & 540 & SV & $\mathbf{M}$ & $100 \mu$ mol Tin-P \\
\hline
\end{tabular}

${ }^{*} \mathrm{C}$, control; $\mathrm{T}$, tin-protoporphyrin treated.

$\dagger \mathrm{CS}$, cesarian section delivery; $\mathrm{SV}$, spontaneous vaginal delivery. $\ddagger$ Estimated at $6 \pm 2 \mathrm{~h}$ method of Jendrassik and Grof (12). Serum unconjugated bilirubin concentrations were estimated from the differences between the total and direct-reacting pigment and accounted for most of the pigment measured. Since it has been previously established that increases in the total serum bilirubin levels in normal neonates are primarily due to elevations in unconjugated pigment as confirmed by high pressure liquid chromatography, it appeared appropriate to present bilirubin levels as the total pigment in serum in Figures 1 and 2 . Since a mild conjugated hyperbilirubinemia was observed in two neonates at $60 \mathrm{~h}$ after tin-protoporphyrin injection, serum bilirubin values were only presented in monkeys T $25 \mathrm{a}$ and $\mathrm{T} 100 \mathrm{~b}$ in Figure 2 prior to this time.

\section{RESULTS}

Neonatal physiologic unconjugated hyperbilirubinemia in six control rhesus neonates receiving $2 \mathrm{ml}$ of saline subcutaneously

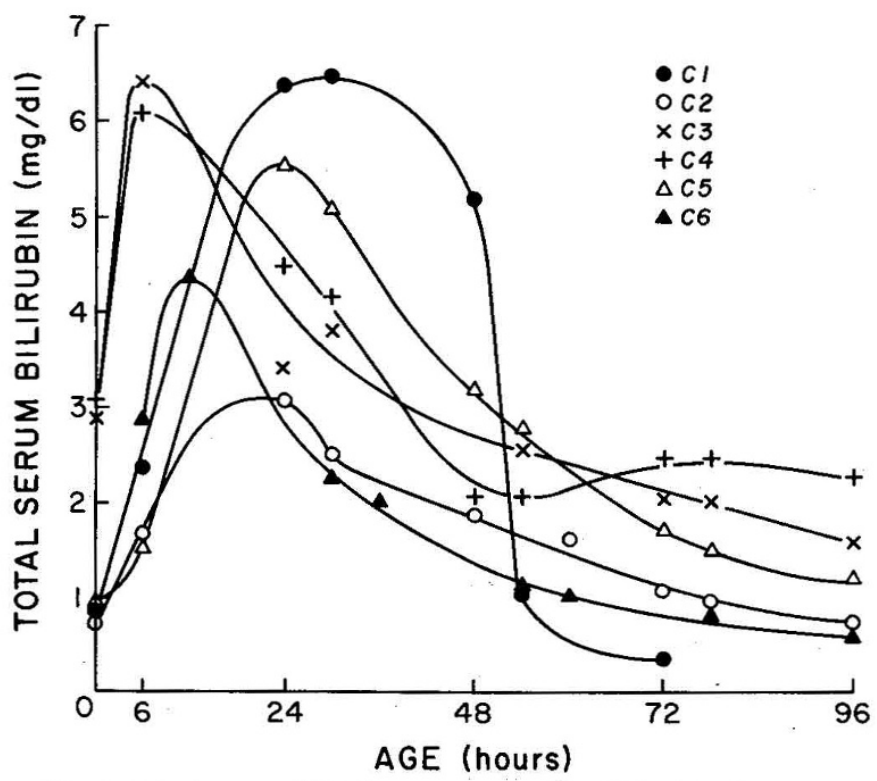

Fig. 1. Total serum bilirubin concentrations (physiologic hyperbilirubinemia) in six control rhesus monkey neonates.

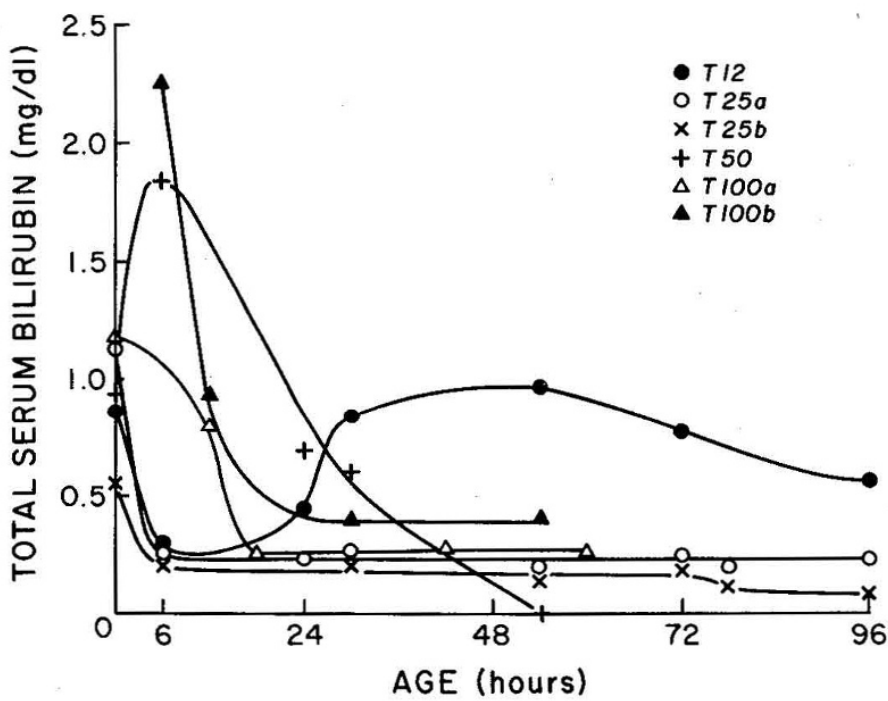

Fig. 2. Total serum bilirubin levels in rhesus monkey neonates in response to the subcutaneous injection of various doses of tin-protoporphyrin. All neonates were injected at the time of birth except for $\mathrm{T} 100 \mathrm{~b}$, which received the metalloporphyrin at approximately $6 \mathrm{~h}$ after birth. Numbers assigned to neonates indicate the dose injected in micromoles. 
is presented in Figure 1. Unconjugated hyperbilirubinemia in neonates following various subcutaneous doses of tin-protoporphyrin at birth can be observed in Figure 2. Please note the different scales of bilirubin concentrations in Figures 1 and 2. Control neonates in all cases exhibited the predicted physiologic hyperbilirubinemia as previously reported by Gartner et al. (10), whereas serum bilirubin levels in all but one infant receiving the tin-protoporphyrin rapidly declined to levels less than $0.4 \mathrm{mg} / \mathrm{dl}$ by $24-30 \mathrm{~h}$. The serum bilirubin concentration in the neonate (T 12) which received the lowest dose (12 $\mu \mathrm{mol})$ of tin-protoporphyrin initially declined rapidly to $0.25 \mathrm{mg} / \mathrm{dl}$ by $6 \mathrm{~h}$ and unexplainably rebounded to $0.95 \mathrm{mg} / \mathrm{dl}$ at $54 \mathrm{~h}$ postinjection.

Two neonates (T 25a, T 100b) that received 25 and $100 \mu \mathrm{mol}$ of tin-protoporphyrin, respectively, exhibited slightly elevated serum direct reacting bilirubin levels of $0.5-0.7 \mathrm{mg} / \mathrm{dl}$ at $60 \mathrm{~h}$ postinjection. These animals subsequently developed differing signs of toxicity following injection. Neonate T 25 a developed a dermatitis after 4 days. Biopsies revealed multiple cutaneous bullae with an intact epidermis and a mild lymphohistiocytic perivascular dermal inflammation. The lesions healed within 3 weeks without scarring and a rechallenge with tin-protoporphyrin at 8 weeks was uneventful. Neonate $T 100 \mathrm{~b}$ died 7 days after injection. Gross observations at necropsy revealed diffuse petechial hemorrhages and edema, hemorrhage, and localized necrosis of the extremities. Gross and histologic examination of liver, spleen, and kidneys showed evidence of infarction; in addition, there was histologic evidence of disseminated arterial thrombosis.

\section{DISCUSSION}

The substantial elevations in heme oxygenase activities in the liver, spleen, and kidneys of rats that occur following birth have been shown to be prevented by a single dose $(10 \mu \mathrm{mol} / \mathrm{kg})$ of tinprotoporphyrin (5). In vitro studies on microsomal heme oxygenase indicate that this metalloporyphyrin is also a potent competitive inhibitor of the oxidation of heme to bilirubin in human spleen (5). These studies suggest that the lowest single effective dose of tin-protoporphyrin IX to prevent postnatal hyperbilirubinemia in rats was $10 \mu \mathrm{mol} / \mathrm{kg}$; doses ranging from 5 to $100 \mu \mathrm{mol} / \mathrm{kg}$ were tested and apparently free from toxicity (5).

Rhesus neonates receiving tin-protoporphyrin also quickly responded by exhibiting decreasing serum levels of unconjugated bilirubin and indicated its effectiveness in inhibiting heme oxygenase activity and bilirubin production in primate species. Since tin-protoporphyrin was administered in the range of $12-100$ $\mu \mathrm{mol}$ in a single dose to the rhesus neonates, the unexplained toxicity in 2 neonates after $54 \mathrm{~h}$ may have been due to either a drug sensitivity or the high level administered in a single dose. Lower levels of drug administration may well prove to be free of toxicity. These observations deserve further study since the multiple administration of amounts totaling $500 \mu \mathrm{mol} / \mathrm{kg}$ of tinprotoporphyrin to neonatal rats has been reported to produce no apparent acute or chronic toxicity $(5,6)$.

Whether this transient suppression of heme oxidation by tinprotoporphyrin IX in neonates could lead to heme accumulation in the serum and tissues and subsequent toxicity is not clear. It is known, however, that daily doses of $800 \mathrm{mg}$ of heme administered to adult patients with hepatic or erythroid porphyria produce no observable toxicity (1). Since heme is a normal constituent of bile and readily appears in bile after its infusion (17), it may not accumulate significantly in tissues following heme oxygenase inhibition. It is apparent from this brief investigation that the use of tin-protoporphyrin IX may prove to be useful in the prevention of neonatal jaundice and deserves further study.

\section{REFERENCES AND NOTES}

1. Bloomer JR, Pierach CA 1982 Effect of hematin administration to patients with protoporphyria and liver disease. Hepatology 2:817

2. Blumenthal SG, Ikeda RM, Ruebner BH 1976 Bile pigments in humans and in nonhuman primates during the perinatal period: composition of meconium and gallbladder bile of newborns and adults. Pediatr Res 10:664

3. Blumenthal SG, Taggert DB, Rasmussen RD, Ikeda RM, Ruebner BH, Bergstrom DE, Hanson FW 1980 Conjugated and unconjugated bilirubins in humans and rhesus monkeys. Structural identity of bilirubins in human prenatal development. Biochem J 186:693

4. Brown AK, Zuelzer WW 1948 Studies on the neonatal development of the glucuronide conjugating system. J Clin Invest 37:332

5. Drummond GS, Kappas A 1982 Chemoprevention of neonatal jaundice: potency of tin-protoporphyrin in an animal model. Science 217:1250

6. Drummond GS, Kappas A 1981 Prevention of neonatal hyperbilirubinemia by tin-protoporphyrin. IX. A potent competitive inhibitor of heme oxidation. Proc Natl Acad Sci USA 78:6466

7. Gartner LM, Arias IM 1963 Developmental pattern of glucuronide formation in rat and guinea pig liver. Am J Physiol 205:663

8. Gartner LM, Arias IM 1969 The transfer of bilirubin from blood to bile in the neonatal guinea pig. Pediatr Res 3:171

9. Gartner LM, Lane DL, Cornelius CE 1971 Bilirubin transport by liver in adult Macaca mulatta. Am J Physiol 220:1

10. Gartner LM, Lee K, Vaisman S, Lane D, Zarufu I 1977 Development of bilirubin transport and metabolism in the newborn rhesus monkey. J Pediatr 90:513

11. Jansen PLM, Chowdhury R, Fischberg EB, Arias IM 1977 Enzymatic conversion of bilirubin monoglucuronide to diglucuronide by rat liver plasma membranes. J Biol Chem 252:2710

12. Jendrassick L, Grof $P 1938$ Verein fachte photometrische Methoden zur Bestimmung des Blutbilirubins. Biochem Z 297:8

13. Lee K, Gartner LW 1983 Management of unconjugated hyperbilirubinemia in the newborn. In: Berk PD (ed) Seminars in Liver Disease, vol 3. ThiemeStratton, Inc., New York, p 52

14. Levi AJ, Gatmaitan Z, Arias IM 1970 Deficiency of hepatic organic anionbinding protein, impaired organic anion uptake by liver and "physiologic" jaundice in newborn monkeys. N Engl J Med 283:1136

15. Maines MD 1981 Zinc protoporphyrin is a selective inhibitor of heme oxygenase activity in the neonatal rat. Biochim Biophys Acta 673:339

16. Maisels MJ, Pathak A, Nielson NM, Nathan DG, Smith CA 1971 Endogenous production of carbon monoxide in normal and erythroblastotic infants. J

Clin Invest 50:1
17. McCormack LR, Liem HH, Strum WB, Grundy SM, Muller-Eberhard U 1982 Effects of haem infusion on biliary excretion of prophyrins, haem and bilirubin in man. Eur J Clin Invest 12:257

18. Poland RL, Odell GB 1971 Physiologic jaundice: the enterohepatic circulation of bilirubin. N Engl J Med 284:1

19. The authors are indebted to Dr. Srinivasa Prahalada for histopathological examinations.

20. This work was supported by National Institutes of Health Grants RR-0016922 and AM-32297-01.

21. Correspondence may be addressed to Dr. Charles E. Cornelius, Director, California Primate Research Center, University of California, Davis, CA 95616.

22. Received for publication November 29, 1983. 